\title{
ISLAM DAN NEGARA MENURUT M. NATSIR DAN ABDURRAHMAN WAHID
}

\author{
Saoki \\ Fakultas Syari'ah dan Hukum UIN Sunan Ampel Surabaya | sauqiamin@gmail.com.
}

\begin{abstract}
This article discusses M. Natsir's and Abdurrahman Wahid's thought about the relationship between Islam and state. Both of $M$. Natsir and Abdurrahman Wahid agree that the most realistic system to be applied in Indonesia is a democratic system. They also agree that there is no a rigid political system in Islam as it has existed today. In addition, Islam provides the basic principles of the nation and state namely deliberation, justice, equality, freedom, and togetherness. The fundamental difference between M. Natsir's and Gus Dur's thought in viewing the relationship between Islam and state is about the two things: first, their respond to secularism, which tries to separate between religion and state; and second, their political thought in addressing democracy and the Pancasila ideology as the fundamental principles of Indonesia.
\end{abstract}

Keywords: Islam, state, M. Natsir, Abdurrahman Wahid.

Abstrak: Artikel ini membahas tentang pemikiran M. Natsir dan Abdurrahman Wahid tentang relasi Islam dan negara. M. Natsir dan Abdurrahman Wahid sama-sama sepakat bahwa sistem yang paling realistis untuk diaplikasikan di negara Indonesia yang majemuk ini adalah sistem demokrasi, dan keduanya sepakat bahwa tidak ada sistem politik yang rigid dalam Islam sebagaimana yang telah ada dewasa ini, dan yang ada dalam Islam hanyalah prinsip dasar berbangsa dan bernegara, seperti musyawarah, keadilan, persamaan, kebebasan, dan kebersamaan. Perbedaan antara pemikiran M. Natsir dan Gus Dur dalam memandang relasi Islam dan negara yang paling fundamental terdapat dua hal: Pertama, respon mereka terhadap paham sekuler, yang memisahkan antara agama dan negara. Kedua, pemikiran politik mereka dalam menyikapi demokrasi dan ideologi Pancasila sebagai dasar negara di Indonesia ini.

Kata Kunci: Islam, negara, M. Natsir, Abdurrahman Wahid 


\section{Pendahuluan}

Gagasan tentang relasi Islam dan negara selalu menjadi wacana aktual di Indonesia meskipun telah diperdebatkan beberapa tahun yang lalu, dan mengalami fluctuative discourse dalam percaturan politik di Indonesia, akan tetapi wacana ini selalu survive pada momen-momen tertentu. Hampir bisa dipastikan ketegangan dan perdebatan ini muncul menjelang pemilu karena momen ini merupakan kesempatan besar bagi semua golongan yang ingin memperjuangkan aspirasi politiknya, baik yang berideologikan nasionalis, maupun Islam.

Sejak Pancasila dijadikan dasar ideologi formal Republik Indonesia pada tahun 1945 oleh Soekarno, Pancasila menjadi bagian perdebatan politik yang tak terelakan oleh Politikus dan Agamawan, khususnya Islam. ${ }^{1}$ Pada tahun 1978-1985 telah terjadi ideologisasi pancasila yang diinstruksikan oleh Soeharto, dan kemudian menimbulkan perdebatan yang luar biasa di kalangan tokoh dan gerakan ideologi Islam. Insiden politik semacam itu sempat terulang kembali pada tahun 1990 di negeri ini, yakni mengenai perdebatan ideologi. Sebenarnya sumber perdebatan itu adalah karena masih belum adanya konsensus mengenai relasi Islam dan negara, ${ }^{2}$ khususnya mengenai sistem negara apa yang akan dipakai untuk membangun Indonesia, apakah berasaskan Islam atau sekuler.

Untuk itu makalah ini mengkaji pemikiran dua tokoh besar bangsa Indonesia, khususnya di kalangan kaum muslim, yaitu M. Natsir dan Abdurrahman Wahid yang akrab dipanggil Gus Dur mengenai relasi agama (Islam) dan negara

\section{Biografi Pemikiran M. Natsir}

M. Natsir lahir pada tgl 17 Jumadil Akhir $1326 \mathrm{H}$, bertepatan dengan tanggal 17 Juli 1908 di Jembatan Berukir Alahan Panjang,

\footnotetext{
' Douglas E. Ramage, Percaturan Politik di Indonesia: Demokrasi, Islam, dan Ideologi Toleransi, alih bahasa Hartono Hadikusumo, (Jogjakarta: Mata Bangsa, 2002), 2.

${ }^{2}$ Ibid., 19.
} 
Kabupaten Solok. Ia merupakan anak ketiga dari pasangan Idris Sutan Saripado dan Khadijah, ${ }^{3}$ pola pemikirannya sedikit banyak dipengaruhi dengan kondisi sosiologis di mana ia tumbuh, yakni saat masyarakat Minangkabau bersemangat bangkit melawan politik kolonial dan mengadakan perubahan doktrin keagamaan

Pendidikan formalnya ditempuh di HIS (Holland Inlandische School) Adabiyah ${ }^{4}$ dan Madrasah Diniyah Solok pada tahun 19161923. setelah lulus dari HIS ia melanjutkan ke $\mathrm{MULO}^{5}$ (Meer Uitgerbreid Lager Onderswij) Padang. M. Natsir mulai terlibat organisasi sejak di MULO, awalnya ia masuk Jong Sumatranen Bond di Padang, dan kemudian beralih ke Jong Islameten Bond (JIB), kedua organisasi tersebut diketuai oleh Sanusi Pane. Pada Juli 1927 ia tamat dari MULO dan melanjutkan ke AMS 6 (Algemene Middelbare School) dengan jurusan sastra Barat (Eropa) klasik di Bandung. ${ }^{7}$

\section{Pemikiran M. Natsir tentang Relasi Islam dan Negara.}

M. Natsir menyatakan dengan tegas bahwa Indonesia merupakan negara Islam, meskipun tidak disebutkan dalam konstitusi, Islam adalah agama negara. Baginya secara de facto sudah pasti menunjukkan bahwa Islam diakui sebagai agama dan

${ }^{3}$ Ajib Rosidi, M. Natsir, Sebuah Biografi, (Jakarta: Girimurti Pustaka, 1990), I45-I 52.

${ }^{4}$ H.I.S. (Hollands Inlandsche School) Adabiyah adalah madrasah sekolah agama yang pertama di Minangkabau, sekolah ini didirikan oleh almarhum Abdullah Ahmad pada 1909. Adabiyah ini berlangsung sebagai sekolah agama sampai tahun 1914, yang kemudian berubah menjadi H.I.S pada tahun 1915.

${ }^{5}$ MULO adalah sekolah rendah dengan program yang diperluas. Sekolah ini berfungsi sebagai subkultur AMS, sekolah kejuruan, dan sekolah terminal bagi mereka yang tidak melanjutkan studinya. Di dalamnya terdiri 4 program bahasa, yaitu: Belanda, Prancis, Inggris, dan Jerman. Setengah waktu digunakan untuk pelajaran bahasa, sepertiga untuk matematika dan ilmu pengetahuan sosial. S. Nasution, Sejarah Pendidikan Indonesia, (Jakarta: Bumi Aksara, 1995), 122 dan 128.

${ }^{6}$ AMS adalah sekolah lanjutan MULO dan sebagai persiapan untuk Universitas di Nederland, oleh sebab itu bahasa pengantar yang digunakan adalah bahasa Belanda. Ibid, |37-|4|.

7 Yusril Ihza Mahendra, "Modernisme Islam dan Demokrasi: Pandangan Politik Natsir," Jurnal ISLAMIKA, no 13, 1994, 65. 
anutan jiwa bangsa Indonesia, bahkan lebih dari itu persoalan kenegaraan di Indonesia tidak bisa dipisahkan dari agama. ${ }^{8}$

M. Natsir beranggapan bahwa urusan kenegaraan pada dasarnya merupakan bagian integral Islam, yang di dalamnya mengandung falsafah hidup atau ideologi seperti kalangan Kristen, Fasis Atau Komunisme. ${ }^{9}$ Dengan berdasarkan hujjah nas al-Qur'an yang dianggapnya mendukung pendapatnya tentang Islam sebagai dasar negara, Natsir menyebutkan QS. al-Dzariyat (51) ayat $56 . .^{10}$ Ia berkesimpulan bahwa cita-cita hidup seorang muslim di dunia ini hanyalah ingin menjadi hamba Allah dengan arti yang sepenuhnya, agar mendapat kejayaan dunia dan akhirat kelak. ${ }^{11}$ Namun demikian, untuk mencapai kejayaan tersebut, Allah telah memberikan aturan-aturan kepada manusia, yaitu aturan atau cara kita berlaku berhubungan dengan Tuhan yang menjadikan kita, dan cara kita berhubungan dengan sesama manusia. Di antaranya aturan-aturan yang berhubungan dengan sesama manusia, yang kemudian di antara aturan-aturan yang berhubungan dengan muamalah sesama makhluk itu, diberikan garis-garis besarnya seseorang terhadap masyarakat, dan hak serta kewajiban masyarakat terhadap diri seseorang, yang saat ini diistilahkan dengan urusan kenegaraan. ${ }^{12}$

Menurut Ahmad Suhelmi ada dua faktor yang mempengaruhi pemikiran M. Nasir: Pertama, faktor sosial politik pada tahun 1940-an yang memunculkan polemik dan pertarungan ideologi antara kaum nasionalis Islam dengan nasionalis sekuler. Kedua, faktor emosional Natsir selaku tokoh negarawan muslim saat itu, akhirnya melahirkan gagasan-gagasan yang cukup reaksioner terhadap pemikiran Soekarno yang cenderung sekuler. ${ }^{13}$

\footnotetext{
${ }^{8}$ M. Natsir, Agama dan Negara Dalam Perspektif Islam, (Jakarta: Media Dakwah, 200 I), 128.

${ }^{9}$ Ahmad Suhelmi, Polemik Negara Islam: Soekarno Versus Natsir, (Bandung: Teraju, 2002), 87.

10 "dan Aku tidak menciptakan jin dan manusia melainkan supaya mereka mengabdi kepada-Ku."

I' M. Natsir, Capita Selecta, (Jakarta: Bulan Bintang, 1973), 436.

${ }^{12} \mathrm{lbid}$.

${ }^{13}$ Ahmad Suhelmi, Polemik Negara Islam, 73.
} 
Sedangkan dalam konteks eforia politik Islam saat itu, wacana tersebut juga sedang hangat diperdebatkan di Timur Tengah karena isu tentang sekulerisme juga sangat kuat di sana, yakni pemisahan antara agama dan negara seperti halnya yang diterapkan Kemal Pasya di Turki. ${ }^{14}$

Di samping itu, banyaknya ide pembaharuan dari tokohtokoh Indonesia dan Timur Tengah yang melekat dalam jiwa Natsir, juga telah ikut mempengaruhi pemikirannya dalam menggagas kenegaraan dalam Islam. Khususnya dalam menyumbangkan pemikirannya tentang bentuk negara Indonesia yang ideal menurut Islam, padahal saat itu Indonesia belum merdeka.

M. Natsir pernah menegaskan dalam pidatonya dalam sidang pleno konstituante 12 November 1957 bahwa mengenai dasar negara Indonesia hanya mempunyai dua pilihan, yaitu sekulerisme; tanpa agama (la diniyyah) dan paham agama (dini). ${ }^{15}$ Dari pernyataan tegas Natsir tersebut diketahui bahwa M. Natsir telah memberikan dua pilihan tersebut sebagai respon atas menguatnya dualisme pemikiran Islam saat itu antara yang menginginkan dasar negara Islam dan sekular.

Paham sekulerisme menurutnya sangat berbahaya dalam membentuk masyarakat ke depan, karena paham ini akan menagakibatkan manusia kehilangan pegangan hidup yang asasnya kokoh, yakni gampang terserang penyakit syaraf dan rohani, seorang sekulerisme memang beranggapan bahwa konsep tentang Tuhan adalah relatif, yakni ditentukan oleh keadaan masyarakat sendiri, bukan oleh wahyu. ${ }^{16}$

Paham inilah yang kemudian menjadi salah satu faktor yang menggerakkan fikiran Natsir, sebagai pemikir Islam. Dengan memperjuangkan Islam sebagai dasar negara. Selain itu

\footnotetext{
${ }^{14}$ Kamarruzaman, Relasi Islam dan Negara: Perspektif Modernis dan Fundamentalis, (Magelang: IndonesiaTera, 200 I), 6I.

15 M. Natsir, Agama dan Negara, 204.

${ }^{16} \mathrm{lbid}$., 206
} 
berdasarkan atas alasan bahwa secara sosiologis, mayoritas penduduk Indonesia adalah muslim, dan masyarakat muslimlah yang mempunyai andil besar dalam mengusir penjajah dari bumi nusantara ini, di samping itu baginya ajaran Islam mempunyai sifat yang sempurna bagi kehidupan negara dalam menjamin keragaman hidup antar berbagai golongan. ${ }^{17}$

Negara menurut Natsir adalah suatu institusi yang mempunyai hak, tugas dan tujuan khusus. Institusi secara umum adalah suatu badan atau organisasi yang mempunyai tujuan khusus dan dilengkapi oleh alat-alat material, peraturan-peraturan sendiri dan diakui oleh umum. ${ }^{18}$

Lebih dari itu, Natsir menambahkan bahwa untuk sesuatu dinamakan institusi apabila:

a. Bertujuan untuk mencukupi kebutuhan masyarakat di lapangan jasmani maupun rohani.

b. Diakui oleh masyarakat.

c. Mempunyai alat untuk melaksanakan tujuan.

d. Mempunyai peraturan-peraturan, norma-norma dan nilainilai tertentu.

e. Berdasarkan atas paham hidup.

f. Mempunyai keanggotaan.

g. Mempunyai daerah berlakunya.

h. Mempunyai kedaulatan atas anggotanya.

i. Memberikan hukuman terhadap pelanggaran atas peraturanperaturan dan norma-normanya. ${ }^{19}$

Negara sebagai suatu institutsi, menurutnya harus mempunyai: a) wilayah. b) rakyat. c) pemerintah. d) kedaulatan. e) Undang-undang Dasar, atau suatu sumber hukum dan kekuasaan lain yang tidak tertulis. ${ }^{20}$

\footnotetext{
${ }^{17}$ Kamarruzaman, Relasi Islam dan Negara, 62.

$18 \mathrm{lbid}$.

${ }^{19}$ lbid., 199.

20 lbid.
} 
Mengenai bersikerasnya M. Natsir dalam memperjuangkan Islam sebagai dasar negara republik ini, karena ia berpandangan bahwa negara bisa menjadi alat yang kokoh bagi berlakunya hukum-hukum Islam. ${ }^{21}$ Dengan demikian negara hanyalah sebuah alat untuk mencapai tujuan, yakni mewujudkan ajaran-ajaran Islam.

Natsir menegaskan bahwa negara bukanlah tujuan akhir Islam, melainkan hanya alat untuk merealisasikan aturan-aturan Islam yang terdapat dalam al-Qur'an dan sunnah, ia menyebutkan bahwa di antara aturan-aturan tersebut yaitu kewajiban belajar, kewajiban zakat, pemberantasan perzinaan dan lain-lain. ${ }^{22}$ Menurutnya, negara di sini berfungsi sebagai alat untuk mencapai tujuan "kesempurnaan berlakunya undang-undang Ilahi, baik yang berkenaan dengan kehidupan manusia sendiri, (sebagai individu) ataupun sebagai anggota masyarakat". ${ }^{23}$

Menurut Natsir, ada atau tidak adanya Islam, eksistensi negara nerupakan keharusan di dunia ini dan di zaman apapun, mendirikan negara tidak perlu disuruh Rasulullah lagi, eksistensi negara telah ada sebelum dan sesudah Islam, Jadi dengan Islam atau tidak tetap saja merupakan sebuah negara. ${ }^{24}$

Melihat pemikiran Natsir tentang dasar negara Indonesia di atas, menimbulkan kesan bahwa Natsir selama perjuangannya adalah anti Pancasila, padahal dalam pidatonya di depan Pakistan Institute of World Affairs pada 1952, sikapnya yang anti Pancasila berubah. Ia menyatakan bahwa:

Tidak diragukan lagi Pakistan adalah sebuah negeri Islam karena telah menyatakan Islam sebagai agama negara, begitu pula Indonesia, menurutnya negara ini juga negeri Islam, karena kenyataannya negara ini diakui sebagai agama rakyat, meskipun dalam konstitusi kami tidak dinyatakan tegas sebagai agama

\footnotetext{
21 lbid., 452.

${ }^{22}$ Ahmad Suhelmi, Polemik Negara Islam, 89.

${ }^{23}$ Natsir, Capita Selecta, 442.

${ }^{24}$ Ibid., 443.
} 
negara. Tetapi Indonesia tidak mengeluarkan agama dari sistem kenegaraan, bahkan kepercayaan tauhid (monothestic belief) telah ditempatkan pada tempat teratas dari sila Pancasila, yang berfungsi sebagai dasar etik, moral dan spritual bangsa dan negara kita. ${ }^{25}$

Natsir mengatakan Pancasila adalah formulasi lima cita-cita kebaikan sebagai hasil dari konsensus para pemimpin kita pada tahap perjuangan sembilan tahun yang lalu. Dan sebagai lima dasar kebaikan tidaklah bertentangan dengan al-Qur'an, kecuali apabila dimasuki oleh sesuatu yang tidak sesuai dengan al-Qur'an. Dalam pandangan umat Islam, rumusan Pancasila tidak memperlihatkan sesuatu yang asing dalam ajaran al-Qur'an, dan meskipun tidak identik dengan Islam itu sendiri, Pancasila telah mencakup cita-cita Islam. Pancasila adalah manifestasi dari maksud dan cita-cita tentang kebaikan dimana kita akan melakukan setiap usaha untuk meletakannya ke dalam praktik negara kita.

Namun kemudian, Natsir terlihat inkonsisten dengan pendiriaannya, pada 1957 di sidang konstituante ia kembali menolak Pancasila sebagai dasar negara, karena ideologi ini dianggap sebagai hasil ciptaan manusia dan tergolong sekuler. Dalan hal ini Syafi'i Ma'arif memandang bahwa mungkin Natsir mengambil sikap keras dalam majelis karena telah terjadi pengaburan interprestai Pancasila yang dibuat-buat oleh masyarakat kita. ${ }^{26}$

Bahkan dalam sidang konstituante tersebut, terang-terangan ia menyatakan bahwa sidang konstituante adalah forum tempat mengemukakan pendapat dan pikiran anggota secara lurus, jujur, dan mencerminkan pemikiran yang hidup di masyarakat. Oleh

\footnotetext{
${ }^{25}$ Kamarruzaman, Relasi Islam dan Negara, 66.

26 Ahmad Syafi'i Maarif, Islam dan Masalah kenegaraan: Studi tentang Percaturan dalam Konstituante, (Jakarta: LP3ES, 1996), 155.
} 
sebab itu ia beranggapan bahwa kesempatan inilah yang tepat untuk menolak Pancasila . ${ }^{27}$

Menurut Njoto, salah satu tokoh komunis, mengatakan bahwa penerimaan Natsir terhadap Pancasila selama 12 tahun sebagai dasar dan ideologi negara sekedar "di bibir saja", karena dalam majelis tersebut, ia sepenuhnya menolak Pancasila ,dan bahkan mengusulkan Islam sebagai dasar dan ideologi negara.

Sebagai seorang demokrat sejati Natsir harus menerima Pancasila sebagai dasar negara, yang telah diberlakukan sejak 1945 sampai tejadinya perdebatan ideologis di majelis konstituante 1957. Namun perlu diketahui bahwa apa yang dilakukan Natsir dalam sidang konstituante tersebut secara konstitusional adalah sah, karena pada saat itu majelis belum menetapkan dasar negara baru yang permanen. Dan sebagaimana tokoh politik yang lain, Natsir sebagai representasi dari pihak muslim berhak mengajukan Islam sebagai dasar negara melawan pendukung Pancasila dalam momen itu.

Perubahan sikap Natsir dalam sidang konstituante saat itu, menurut Deliar Noer dipicu oleh tiga alasan. Pertama, majelis konstituante merupakan forum tertinggi bagi para anggotanya untuk mengusulkan ideologi negara yang mereka yakini dan cocok untuk negara Indonesia. Kedua, dalam majelis, Natsir dan teman-temanya memikul tanggung jawab agama dan politik dalam memperjuangkan aspirasi politik umat Islam, yang menginginkan Islam sebagai dasar negara. Ketiga, sebagaimana wakil-wakil non muslim yang menjelaskan argumentasi usulan mereka, Natsir juga menjelaskan usulannya secara argumentatif pula. ${ }^{28}$

Ketika Natsir berbicara tentang sistem pemerintahan demokrasi, perlu dicermati lebih lanjut, sebab dalam pandangannya prinsip musyawarah dalam Islam tidak selalu

\footnotetext{
27 Deliar Noer, Partai Islam, Partai Islam di Pentas Nasional: Kisah dan Analisis Perkembangan Politik Indonesia 1945- 1965, (Bandung: Mizan, 2000), I4I.

${ }^{28}$ Deliar Noer, Partai Islam, 284-285.
} 
identik dengan azas demokrasi, meskipun ia mengemukakan bahwa Islam anti istibdad (despostisme), anti absolutisme dan kesewenang-wenangan. ${ }^{29}$ Bukan berarti bahwa dalam pemerintahan Islam semua urusan diserahkan kepada keputusan majelis Syura, sebab Dalam parlemen negara Islam yang boleh dimusyawarahkan hanyalah masalah tata cara pelaksanaan hukum Islam (syari'at Islam), bukan dasar negaranya. ${ }^{30}$

Dalam Islam pengertian demokrasi diartikannya suatu aturan yang memberikan hak kepada rakyat untuk mengkritik dan membetulkan pemerintahan yang zalim, kalau perlu menggunakan kekuatan dan kekerasan untuk menghilangkannya. ${ }^{31}$

Natsir mengakui bahwa demokrasi itu baik, akan tetapi sistem kenegaraan Islam tidaklah menggantungkan semua urusannya kepada instrumen demokrasi, menurutnya demokrasi tidak kosong dari berbagai bahaya yang terkandung di dalamnya. Ia menyatakan bahwa perjalanan demokrasi dari abad ke abad telah memperlihatkan beberapa sifatnya yang baik. Akan tetapi bukan berarti ia lepas sama sekali dari pelbagai sifat-sifat bahaya. ${ }^{32}$

Dari uraian di atas, Natsir tidak menjelaskan bagaimana sesungguhnya demokrasi dalam Islam. Namun kemudian dalam sidang konstituante 1957 ia memperkenalkan konsep demokrasi yang ia maksudkan, "thestic democracy", yaitu demokrasi yang dilandasakan pada nilai-nilai ketuhanan. ${ }^{33}$ Maksudnya keputusan mayoritas yang berpedoman kepada nilai-nilai ketuhanan, yang kemudian ia anggap sebagai ijma' yang mengikat untuk tempat dan zaman tertentu.

\footnotetext{
${ }^{29}$ Ahmad Suhelmi, Polemik Negara Islam, 91.

30 M. Natsir, Capita Selecta, 452.

31 lbid., 439.

32 lbid., 452.

33 lbid.
} 


\section{Biografi Abdurrahman Wahid}

Gus Dur dilahirkan di Denanyar, Jombang, pada tanggal 4 sya'ban menurut penanggalan Islam, yang kemudian bertepatan dengan tanggal 7 September 1940 M. Namun demikian perayaan hari kelahirannya selalu diadakan pada tanggal 4 Agustus, ${ }^{34}$ hal ini memang aneh, sebagaimana terlihat dalam aspek kepribadiannya yang nyleneh pula, seringkali mengundang kontroversial.

Gus Dur memulai pendidikan formalnya di Sekolah Rakyat (SD) KRIS, di Jakarta Pusat. Ia hanya mengikuti kelas tiga dan empat di sekolahan ini, karena kemudian ia pindah ke Sekolah Dasar Matraman Perwari, yang terletak di dekat rumah keluarganya yang baru di Matraman, Jakarta Pusat. ${ }^{35}$

Pada tahun 1953, Gus Dur tamat dari sekolah dasarnya di Jakarta. Lalu setahun setelah tamat SD, pada tahun 1954 ia melanjutkan ke Sekolah Menengah Ekonomi Pertama (SMEP) di Yogyakarta dan berhasil menamatkannya pada tahun 1956.36 Setelah tamat dari SMEP di Yogyakarta pada tahun 1957, Gus Dur mulai mengikuti pelajaran pesantren secara penuh, tepatnya di pesantren Tegalrejo Magelang, yang terletak di sebelah utara kota Yogyakarta. Ia belajar di pesantren ini dari tahun 1957-1959 pada Kiai Khudori, salah satu pemuka NU. ${ }^{37}$

Kemudian pada tahun 1959, Gus Dur pindah ke pesantren Tambak beras Jombang. Di bawah bimbingan Kiai Wahab Chasbullah, sampai pada tahun 1963.38 Pada masa-masa itulah (sejak akhir 1950-an sampai 1963) Gus Dur mengalami konsolidasi

${ }^{34}$ Greg Barton, Biografi Gus Dur, The Authorized Biography of Abdurrahman Wahid, (Yogyakarta: LKiS, 2003), 25.

35 Ibid., 40.

${ }^{36}$ Hartono Ahmad Jaiz, Gus Dur Menjual Bapaknya, Bantahan Pengantar Buku: Aku Bangga Jadi Anak PKI, (Jakarta: Darul Falah, 2003), 30.

${ }^{37}$ Di bawah asuhan Kiai Khudori, Gus Dur termasuk santri yang cerdas dan berbakat. Karena kebanyakan para santri di sini menghabiskan waktu studinya selama empat tahun sedangkan Gus Dur cuma dua tahu, selain di pesantren Gus Dur juga menghabiskan sebagaian besar waktunya di luar kelas dengan membaca buku-buku Barat. Lihat Greg Barton, Biografi Gus Dur, 50.

38 Umaruddin Masdar, Membaca Pikiran Gus Dur dan Amien Rais tentang Demokrasi, (Yogyakarta: Pustaka Pelajar, 1999), 119. 
dalam studi formalnya tentang Islam dan sastra Arab klasik. Setelah menimba ilmu dari pesantren-pesantren di atas, pada tahun 1964 Gus Dur memperoleh kesempatan belajar ke Universitas al-Azhar Kairo Mesir, melalui beasiswa Departemen Agama. ${ }^{39}$ Dari Kairo Gus Dur pindah ke Irak, untuk mengikuti kuliah di Universitas Baghdad, Fakultas Sastra, selama empat tahun. ${ }^{40}$

Setelah itu, akhirnya Gus Dur kembali lagi ke Indonesia dan kehidupan pesantren. Pada tahun 1972-1974, ia menjadi dosen dan dekan Fakultas Ushuluddin di Universitas Hasyim Asy'ari (UNHASY), yang sekarang menjadi Institut Keislaman Hasyim Asy'ari (IKAHA), Jombang. Kemudian dari tahun 1975-1979, ia menjadi sekretaris umum pondok pesantren Tebuireng, Jombang. ${ }^{41}$

Selama periode ini, Gus Dur juga banyak terlibat dalam kepemimpinan nasional NU. Sampai akhirnya pada tahun 1979 ia hijrah ke Jakarta, dan mengawali kariernya di PB NU sebagai katib awal Syuriah NU, dan menjadi dosen IAIN Syarif Hidayatullah, sebelum akhirnya mendirikan Pesantren Ciganjur, di Jakarta Selatan. ${ }^{42}$ Selain itu, ia juga banyak terlibat dalam berbagai proyek dan aktivitas di Jakarta termasuk mengajar di dalam program pelatihan bulanan kependetaan Protestan. ${ }^{43}$

Pada tahun 1998 pasca reformasi, Gus Dur yang saat itu masih aktif menjabat ketua umum PBNU mendirikan sebuah Partai Kebangkitan Bangsa (PKB), pada tanggal 23 Juli 1998, dengan menyatakan bahwa PKB bukanlah Partai Islam dan merupakan partai yang menginginkan negara sekuler. ${ }^{44}$ Dengan

${ }^{39}$ Dedy Djamaluddin Malik, dan Idy Subandy Ibrahim, Zaman Baru Islam Indonesia: Pemikiran dan Aksi Politik Abdurrahman Wahid, M. Amien Rais, Nurcholis Madjid, dan Jalaluddin Rakhmat, (Bandung: Zaman Wacana Mulia, 1998), 83.

${ }^{40}$ Ibid., 165.

${ }^{41}$ Greg Barton dan Greg Fealy, Tradisionalisme Radikal, Persinggungan Nahdlatul Ulama Negara, (Yogyakarta: LKiS, 1997), 165.

${ }^{42}$ Abdurrahman Wahid, Mengurai Hubungan Agama dan Negara, (Jakarta: Grasindo, 1999), 33.

${ }^{43}$ Greg Barton dan Greg Fealy, Tradisionalisme Radikal, 165.

${ }^{44}$ Bahrul Ulum, Bodohnya NU Apa NU Dibodohi?, Jejak Langkah NU Era Reformasi: Menguji Khittah Meneropong Paradigma Politik, (Yogyakarta: Ar-Ruzz: 2002), I35- 136. 
dukungan PKB dan Partai-Partai Islam yang dinamakan "poros tengah" saat itu, telah berhasil mengantarkannya pada kursi kepresidenan pada tahun 1999 di masa reformasi ini.

\section{Pemikiran Abdurrahman Wahid tentang Relasi Islam dan Negara}

Masalah relasi Islam dan negara merupakan salah satu hal yang penting dalam pemikiran Gus Dur, oleh sebab itu banyak orang yang melakukan review terhadap pemikirannya. Secara garis besar bisa dikatakan bahwa arus pemikiran Gus Dur mengenai relasi Islam dan negara dapat dikategorikan sebagai pemikiran yang sekularistik, yaitu pemisahan antara agama dan negara, yang sejalan dengan pemikiran Ali Abd al-Raziq.

Berbeda dengan M. Natsir dengan berbagai alasannya di atas, yang menginginkan Islam dijadikan kekuatan ideologi dan dasar negara ini. Gus Dur sebaliknya, ia menolak Islam dijadikan ideologi, karena menurutnya kalau agama, politik dan budaya diideologikan fungsinya akan terdistorsi dan bukan malah mendapatkan struktur yang lebih baik, melainkan justru akan memicu disintegrasi yang berbasis sekretarian dan konflik horizontal. ${ }^{45}$

Menurutnya, ada dua alasan mengapa ia menolak didirikannya negara Islam. ${ }^{46}$ Pertama, argumentasi normatifteologis, yang menyebutkan bahwa daulah Isla>miyyah (Islamic State) tidak pernah disebutkan secara eksplisit dalam al-Qur'an. Memang dalam al-Qur'an ada ayat yang berbunyi baldatun tayibatun wa rabbun gafur, sebuah ayat yang lebih pada konteks sosiologis, yaitu negara yang baik, penuh pengampunan Tuhan. Atas dasar inilah Islam tidak memberi konsep yang jelas, melainkan hanya memberi nilai etik bagi kehidupan bangsa dan negara.

${ }^{45}$ Dedy Djamaluddin Malik, dan Idy Subandy Ibrahim, Zaman Baru Islam, 78.

${ }^{46}$ Khamami Zada, Neraca Gus Dur di Panggung Kekuasaan, (Jakarta: Lakpesdam, 2002), 122123. 
Kedua, argumentasi historis, yaitu berkaitan dengan fakta bahwa dalam sejarah Islam tidak pernah menunjukan adanya mekanisme baku bagaimana suksesi dalam Islam. Ini bisa dilihat dari keempat khalifah pertama sepeninggalnya Rasulullah, semuanya diangkat melalui mekanisme yang berbeda satu sama lain, padahal pengangkatan seorang kepala negara merupakan kunci utama untuk mengetahui sistem kenegaraan.

Selain itu, dalam konteks negara pluralistik seperti Indonesia, menjadikan Islam atau agama apapun sebagai ideologi negara hanya akan memicu disintegrasi bangsa, karena menurutnya sangat tidak mungkin memberlakukan formalisme agama tertentu dalam komunitas agama masyarakat yang sangat beragam. Oleh sebab itu, baginya pluralitas merupakan hukum alam atau Sunnatullah di negeri ini, dan seharusnya Islam dijadikan sebuah nilai etik sosial (social ethics), yang berarti Islam berfungsi komplementer dalam kehidupan negara. ${ }^{47}$

Baginya Islam adalah agama yang penuh dengan kasih sayang, toleran dan keadilan. Untuk itu Gus Dur sepakat dengan aksioma bahwa Islam adalah agama pembebasan (a liberating religion), yang lahir dalam konteks protes terhadap ketidakadilan di tengah komersial Arab dengan nilai-nilai dasarnya, seperti musyawarah, persamaan dan keadilan. ${ }^{48}$

Pemaksaan formalisasi hukum Islam melalui struktur negara, bagi Gus Dur, merupakan pengingkaran terhadap demokrasi yang ingin ditegakkan di negeri ini, padahal dalam negara demokrasi nilai egalitarianisme sangatlah dijunjung tinggi, bukan malah menjadikan pemeluk agama lain menjadi warga negara kelas dua. ${ }^{4}$

\footnotetext{
${ }^{47}$ Umaruddin Masdar, Membaca Pikiran Gus Dur, 129.

${ }^{48}$ Ibid., 127.

${ }^{49}$ Abdurrahman Wahid, Mengurai Hubungan Agama, 169.
} 
Dalam pandangan Greg Barton, Fachry Ali, dan Bachtiar Effendi, Gus Dur dikategorikan dalam aliran neo-modernis. ${ }^{50}$ Ini dikarenakan gagasan-gagasannya yang liberal dan tetap menggunakan esensi khazanah pemikiran tradisional (legacy of past).

Berkaitan dengan ideologi Pancasila, Gus Dur juga menyatakan bahwa tanpa Pancasila negara Indonesia akan bubar, ideologi ini merupakan asas negara yang harus dimiliki dan diperjuangkan, tidak peduli apakah ia dikebiri angkatan bersenjata, dimanipulasi umat Islam, atau malah disalahgunakan oleh keduanya.

Ini merupakan pernyataan yang penuh resiko pada tahun 1990-an, karena pada saat itu rakyat Indonesia sudah sangat bosan dan jenuh mendengar Pancasila yang selalu disebut oleh pejabatpejabat dan hampir setiap hari dipropogandakan dalam media massa. Seolah-olah Pancasila saat itu telah menjadi mantra pemerintahan dalam menjalankan kebijakan, dan sempat menjadi ejekan karena semua kegiatan harus berlabelkan Pancasila, seperti pers Pancasila, ekonomi Pancasila, bahkan sepak bola Pancasila.

Mengenai relasi antara agama dan negara yang selalu menimbulkan ketegangan sejak periode awal Indonesia merdeka, antara kaum nasionalis dan kaum muslim. Gus Dur sebagaimana K.H. Achmad Siddiq, berupaya untuk mencairkan ketegangan tersebut, dengan menyatakan bahwa Islam sebagai agama memberlakukan nilai-nilai normatif dalam kehidupan perorangan maupun kolektif, sedangkan negara tidak mungkin memberlakukan nilai-nilai yang tidak diterima oleh masyarakat yang berbeda-beda agama dan pandangan hidupnya. ${ }^{51}$

Untuk mendukung tujuan-tujuan demokratis dan sosialnya, Gus Dur lebih sering menggunakan ideologi Pancasila daripada

50 Fachry Ali dan Bachtiar Effendi, Merambah Jalan Baru Islam: Rekonstruksi Pemikian Islam Indonesia Masa Orde Baru, (Bandung: Mizan, 1990), 29-81.

${ }^{51}$ Abdurrahman Wahid, Islam, Ideologi dan Etos Kerja di Indonesia, dalam Budhy Munawar Rahman, Doktrin Islam Dalam Sejarah, (Jakarta: Paramadina, 1995), 583. 
Islam dalam melegitimasi partisipasinya dalam wacana politik dan pengekspresian gagasan kunci politiknya. Dari sini bisa dilihat bahwa pemikiran politiknya didasarkan pada visi politik yang demokratis, sekular dan nasionalis. ${ }^{52}$

Bagi Gus Dur Pancasila adalah ideologi nasional yang esensial untuk mempertahankan kesatuan nasional. Pandangan ini menurutnya penting untuk disampaikan karena beberapa muslim memandang Pancasila sebagai ideologi sekular yang tidak sesuai dengan Islam. Ia kemudian menunjukkan bahwa ayahnya, Wahid Hasyim, seorang pemimpin NU pada tahun 1945 juga sepakat mendukung sebuah negara nasional non Islam.

Berdasarkan uraian di atas, dapat diketahui beberapa hal pemikiran Gus Dur mengenai hubungan Islam dan negara. Pertama, Gus Dur selalu ingin menjaga independensi keberagamaan masyarakat dalam menghadapi negara, karena ketaatan seseorang harus muncul dari kesadaran pribadi, bukan dari paksaan negara.

Kedua, penolakan Gus Dur terhadap sebagian masyarakat muslim yang ingin menjadikan Islam sebagai ideologi negara, merupakan konsekuensi dari pemahaman demokrasi yang ia perjuangakan, yakni menempatkan masyarakat secara egaliter di hadapan negara. Karena pengistimewaan agama tertentu dalam negara yang plural ini, berarti pengingkaran nilai-nilai demokrasi.

Ketiga, negara tidak boleh mengintervensi urusan-urusan agama masyarakat. Begitu juga sebaliknya agama tidak perlu mengemis legitimasi kepada negara karena hal tersebut bukan menguatkan eksistensi agama sebagai kepercayaan, melainkan justru merendahkan.

\section{Persamaan Pemikiran M. Natsir dan Abdurrahman Wahid}

Dalam sejarah politik Indonesia, M. Natsir dan Gus Dur dikenal sebagai pemikir muslim yang sekaligus praktisi politik

52 Douglas E. Ramage, Demokrasi, Toleransi Agama Dan Pancasila: Pemikiran Politik Abdurrahman Wahid, dalam Greg Barton dan Greg Fealy, Tradisionalisme Radikal, 194. 
terkemuka di negeri ini, keduanya sama-sama mempunyai komitmen untuk menjadikan Islam sebagai agama pembebas yang membebaskan manusia dari segala bentuk eksploitasi dan diskriminasi.

Sisi persamaan yang dominan antara M. Natsir dengan Gus Dur dalam membangun relasi Islam dan negara adalah pengakuan mereka tentang tidak adanya sistem politik yang rigid dalam Islam sebagaimana yang telah ada dewasa ini, dan yang ada dalam Islam hanyalah prinsip dasar berbangsa dan bernegara, seperti musyawarah, keadilan, persamaan, kebebasan, dan kebersamaan.

Menurut Natsir, dalam kenegaraan, Islam hanyalah mengatur dasar dan pokok-pokokmya saja seperti yang dinyatakan di atas, maka dari itu dalam membangun sebuah negara M. Natsir banyak menggunakan syarat-syarat sebuah negara modern, di antaranya harus mempunyai wilayah, rakyat, Pemerintah, Kedaulatan, Undang-Undang Dasar atau sumber hukum atau kekuasaan lain yang tidak tertulis. ${ }^{53}$

Masih dalam konteks yang sama, Gus Dur juga menyatakan secara tegas bahwa Islam tidak memberi konsep yang jelas untuk membangun sebuah negara, melainkan hanya memberi nilai etik bagi kehidupan bangsa dan negara. Secara historis juga telah terbukti bahwa dari keempat khalifah sepeninggalnya Rasulullah, semuanya diangkat melalui mekanisme yang berbeda satu sama lain, ini menunjukkan bahwa Islam memang tidak mempunyai mekanisme baku sebuah suksesi, padahal pengangkatan seorang kepala negara merupakan kunci utama untuk mengetahui sistem kenegaraan.

Oleh sebab itu, sistem demokrasi menurut kedua tokoh tersebut merupakan sistem yang paling realistik untuk mewujudkan terbentuknya suatu masyarakat yang adil, egaliter dan manusiawi sebagaimana yang dicita-citakan Islam. Karena dengan adanya nilai-nilai dasar di atas Islam bisa dikatakan

${ }^{53}$ Natsir, Capita Selecta, 199. 
sebagai agama pembebas sepenuhnya kompatibel dengan aturan demokrasi.

Sebagaimana Abduh, M. Natsir menganggap sumber kekuasaan bagi pemerintahan adalah rakyat. Karena itu, demokrasi yang berdasarkan doktrin kedaulatan rakyat diterima secara terbuka, akan tetapi bukan berarti ia menerima konsep sekulerisme sebagaimana yang inheren dalam sistem demokrasi Barat. Oleh sebab itu ia menawarkan sebuah konsep thestic democracy, yaitu demokrasi yang sesuai dengan prinsip tauhid. Menurutnya, Syari'ah sebagai suatu sistem hukum terpadu dan lengkap hanya bisa dilaksanakan apabila ada suatu otoritas yang melaksanakan penerapan (law enforcement), sehingga pelaksanaan Syari'ah memerlukan dukungan kekuasaan politik, yaitu negara. Dengan demikian tujuan pertama didirikannya negara demokrasi adalah untuk menjaga dan melindungi syari'at itu sendiri.

Sedangkan Gus Dur ingin menegakkan demokrasi yang seutuhnya, artinya tidak ada tendensi agama yang melekat pada konsep ini. Dengan demikian ada perbedaan yang sangat mendasar mengenai paradigma dalam memperjuangkan konsep demokrasi, meskipun keduanya sama-sama menerima demokrasi secara terbuka. Dan sebenarnya sikap ini sudah jelas terlihat di atas, bagaimana reaksi dan sikap keduanya dalam memandang Pancasila di negeri ini.

Atas dasar pemahaman, Islam mempunyai prinsip-prinsip dasar dalam berbangsa dan bernegara, maka keduanya sepakat untuk menjadikan demokrasi sebagai sistem yang paling rasional untuk negara republik ini. Terlepas bagaimana cara kedua tokoh itu dalam memperjuangkannya.

\section{Perbedaan Pemikiran M. Natsir dan Abdurrahman Wahid}

Perbedaan antara pemikiran M. Natsir dan Gus Dur dalam memandang relasi Islam dan negara yang paling fundamental terdapat dua hal. Pertama, respon mereka terhadap paham sekuler, yang memisahkan antara agama dan negara. Kedua, pemikiran 
politik mereka dalam menyikapi demokrasi dan ideologi Pancasila sebagai dasar negara di Indonesia ini.

Berangkat dari wacana relasi Islam dan negara di atas, M. Natsir dengan tegas menolak negara yang berdasarkan sekularisme, menurutnya sekularisme adalah suatu cara hidup yang mengandung paham, tujuan, dan sikap yang hanya sebatas keduniawian saja. Walaupun para sekularis mengakui adanya Tuhan, tapi dalam kehidupan sehari-harinya tidak menganggap perlu adanya hubungan jiwa dengan Tuhan, baik dalam sikap, tingkah laku, ibadah dan tindakan sehari-harinya.

Ditarik dalam konteks Indonesia, tampaknya M. Natsir ingin membuktikan bahwa Indonesia telah terkontaminasi dengan paham ini. Baginya dengan adanya konsep Pancasila berarti telah terbukti bahwa negara Indonesia telah terjangkit penyakit sekularisme, karena konsep ini jelas bercorak la-diniyyah yang tidak mau mengakui wahyu sebagai sumbernya, di samping itu Pancasila adalah hasil penggalian dari masyarakat. ${ }^{54}$

Dilihat dari beberapa pernyataan Natsir pada bab-bab sebelumnya, bisa dikatakan bahwa hubungan Islam dan negara, menurutnya tidak dapat dipisahkan, karena keduanya mempunyai fungsi timbal balik, simbiosis mutualisme. Baginya, negara adalah sebuah alat bukan tujuan, berarti negara di sini selain merupakan institusi pemerintahan, juga mempunyai kekuatan penuh untuk menjaga dan memberlakuan undangundang Syari'ah, yang berkenaan dengan kehidupan manusia sebagai individu, maupun masyarakat secara kolektif. ${ }^{55}$

Sedangkan Gus Dur, lebih mengasumsikan agama sebagai sumber motivasi pandangan hidup bangsa atau ideologi negara (Pancasila). Maksudnya agama berperan mendorong kegiatan individu melalui nilai-nilai yang diserap Pancasila dengan

\footnotetext{
${ }^{54}$ Ahmad Syafi'i Maarif, Islam dan Masalah Kenegaraan, 127.

55 Natsir, Capita Selecta, 442.
} 
menjadikannya sebagai bentuk pandangan hidup bangsa. ${ }^{56}$ Jadi agama di sini hanyalah bersifat dialogis bukan simbiosis.

Pola pemikiran Gus Dur ini bisa dikategorikan cukup sekuler, mengingat gagasan yang ia hasilkan selalu mengesampingkan simbolisasi agama terhadap negara atau sebaliknya. Ia tidak pernah berkeinginan untuk memanfaatkan negara sebagai alat pemberlakuan hukum agama tertentu, seperti tuntutan diberlakuannya syariah oleh negara, karena menurutnya hanya akan menciptakan diskriminasi agama.

Selain itu, demokrasi yang menurut Natsir dan Gus Dur merupakan konsep paling rasional untuk sistem negara. Secara tegas dikatakan Natsir, Islam tetap tidak perlu menganut demokrasi $100 \%$, dan konsep demokrasi yang cocok bagi Indonesia adalah demokrasi yang tidak meninggalkan nilai-nilai ketuhanan, thestic democracy, maksudnya, keputusan mayoritas yang berpedoman pada ketuhanan. ${ }^{57}$ Ini menunjukkan bahwa Natsir selaku tokoh modernis muslim sangat selektif dalam menerapkan filterisasi (saringan) terhadap Barat.

Dalam modernisasi politik Islam, Natsir mempunyai pandangan untuk berusaha menerapkan ajaran dan nilai-nilai, kerohanian, sosial, dan politik Islam yang terkandung di dalam alQur'an dan sunnah dengan menyesuaikan terhadap perkembangan zaman. Selanjutnya, Natsir mewajibkan seoarang muslim untuk berpolitik sebagai sarana dakwah Islam. ${ }^{58}$

Berbeda dengan Natsir, Gus Dur menilai demokrasi sebagai suatu kedaulatan rakyat sepenuhnya, ia tidak sepakat kalau urusan Tuhan dicampuradukkan dalam kepentingan ini. Baginya demokrasi adalah urusan manusia yang diberi kebebasan untuk mengatur dunia, sedangkan kedaulatan Tuhan (Syari'ah)

\footnotetext{
${ }^{56}$ Abdurrahman Wahid, Mengurai Hubungan Agama dan Negara, 92.

${ }^{57}$ Yusril Ihza Mahendra, "Modernisme Islam dan Demokrasi: Pandangan Politik M. Natsir," 79.

${ }^{58}$ Thoir Luth, M. Natsir: Dakwah dan Pemikirannya, (Jakarta: Gema Insani Press, 1999), 85.
} 
merupakan prinsip-prinsip universal yang menjadi patokan etik moral bagi kehidupan berbangsa dan bernegara. ${ }^{59}$

Natsir dan Gus Dur sama-sama terlibat dalam pemerintahan, akan tetapi keduanya mempunyai tujuan politik yang berbeda, Natsir masuk dalam birokrasi pemerintahan berharap akan bisa memperjuangkan pemeberlakuan syari'ah Islam melalui otoritas negara. Sedangkan Gus Dur justru sebaliknya, ia malah berkeinginan untuk meminimalisir intervensi negara terhadap agama, termasuk penolakannya terhadap pemberlakuan syari'ah di negara ini.

Di samping paradigma, faktor perbedaan masa kehidupan juga cukup mempengaruhi pola pemikiran keduanya, di mana Natsir hidup pada masa kolonial dan pasca kolonial yang selalu berjuang memerdekakan bangsa ini melalui jargon Islam. Sedangkan gagasan dan perjuangan Gus Dur dihadapkan pada masa 1980-an, pasca kolonial. Namun demikian, apa yang dihadapi Gus Dur tentang wacana keislaman sebenarnya juga masih banyak diwarnai wacana-wacana keislaman di masa Natsir hidup.

Perbedaan paradigma dan masa itulah yang kemudian melahirkan polarisasi aliran, antara modernisme dan neomodernisme. Gerakan modernisme di Indonesia lahir sejak tahun 1912-an, sebagai salah satu respon intelektual terhadap berbagai persoalan aktual modern yang secara umum menempatkan Islam pada posisi dilematis, antara keharusan menyesuaikan diri dengan perubahan arus modernitas atau menegaskan diri sebagai agama secara eksklusif.

Modernisme Islam mempunyai kecenderungan kuat untuk mengembalikan kejayaan dan keunggulan Islam atas partai atau peradaban yang lain, dengan cara memperbaharui doktrin-doktrin sesuai dengan tuntutan zaman. Secara teoritis gerakan ini cenderung eksklusif karena dasar argumentasinya lebih

\footnotetext{
${ }^{59}$ Umaruddin Masdar, Membaca Pikiran Gus Dur dan Amien, 176.
} 
ditekankan pada sumber syari'ah yang absolut, al-Qur'an dan sunnah.

Lain halnya, dengan pemikiran neo-modernisme Islam, yang baru lahir pada masa 1970-an. Kalangan ini cenderung akomodasionis dalam merespon tradisionalisme dan modernisme. Menurutnya, sikap modernitas seharusnya tidak menggantikan sama sekali nilai-nilai lama dengan nilai-nilai baru, seperti apa yang diungkapkan oleh mayoritas kalangan modernis Islam, melainkan bahwa antara tradisi dan modernitas harus dilihat sebagai proses kontinuitas. ${ }^{60}$

\section{Penutup}

Dari uraian di atas, bisa dipahami bahwa mengenai relasi Islam dan negara, meskipun secara teoritis keduanya sepakat bahwa Islam tidak mempunyai sistem kenegaraan yang baku, akan tetapi secara praksis aksi politik mereka berbeda. Menurut M. Natsir, Islam dan negara adalah dua entitas yang tidak bisa dipisahkan (integratif). Ia beranggapan bahwa urusan kenegaraan pada dasarnya merupakan bagian integral Islam yang di dalamnya mengandung ideologi atau falsafah hidup. Sementara menurut Gus Dur, antara agama dan negara harus dipisahkan secara jelas fungsi wewenangnya (sekular), supaya tidak terjadi pendistorsian. Dan seharusnya Islam hanya dijadikan sebagai etika sosial saja dalam kehidupan bernegara, bukan sebagai landasan ideologi.

Lebih jauh dapat dipahami bahwa meskipun secara historis kondisi sosial politik M. Natsir dan Gus Durg berbeda, akan tetapi secara ideologis perjuangan dan cita-cita politik, mereka masih terus mewarnai panggung politik Indonesia hingga saat ini, dan mudah-mudahan semua sumbangsih pemikiran keduanya dalam bidang politik dapat bermanfaat bagi kesejahteraan hidup bangsa Indonesia dan menjadi bagian dari amal shaleh yang diterima oleh Allah swt.

${ }^{60}$ Dedy Djamaluddin Malik, dan Idy Subandy Ibrahim, Zaman Baru Islam, I 82.

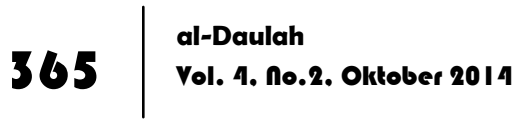




\section{Daftar Pustaka}

Ali, Fachry dan Bachtiar Effendi. Merambah Jalan Baru Islam: Rekonstruksi Pemikian Islam Indonesia Masa Orde Baru. Bandung: Mizan, 1990.

Barton, Greg dan Greg Fealy. Tradisionalisme Radikal, Persinggungan Nahdlatul Ulama Negara. Yogyakarta: LKiS, 1997.

-------. Biografi Gus Dur, The Authorized Biography of Abdurrahman Wahid. Yogyakarta: LKiS, 2003.

Jaiz, Hartono Ahmad. Gus Dur Menjual Bapaknya, Bantahan Pengantar Buku: Aku Bangga Jadi Anak PKI. Jakarta: Darul Falah, 2003.

Kamarruzaman. Relasi Islam dan Negara: Perspektif Modernis dan Fundamentalis. Magelang: IndonesiaTera, 2001.

Luth, Thoir. M. Natsir: Dakwah dan Pemikirannya. Jakarta: Gema Insani Press, 1999.

Maarif, Ahmad Syafi'i. Islam dan Masalah Kenegaraan: Studi tentang Percaturan dalam Konstituante. Jakarta: LP3ES, 1996.

Mahendra, Yusril Ihza. "Modernisme Islam dan Demokrasi: Pandangan Politik Natsir," Jurnal Islamika, no 13, 1994.

Malik, Dedy Djamaluddin dan Idy Subandy Ibrahim. Zaman Baru Islam Indonesia: Pemikiran dan Aksi Politik Abdurrahman Wahid, M. Amien Rais, Nurcholis Madjid, dan Jalaluddin Rakhmat. Bandung: Zaman Wacana Mulia, 1998.

Masdar, Umaruddin. Membaca Pikiran Gus Dur dan Amien Rais tentang Demokrasi. Yogyakarta: Pustaka Pelajar, 1999.

Nasution, S. Sejarah Pendidikan Indonesia. Jakarta: Bumi Aksara, 1995.

Natsir, M. Capita Selecta, Jakarta: Bulan Bintang, 1973.

- Agama dan Negara Dalam Perspektif Islam. Jakarta: Media Dakwah, 2001.

Noer, Deliar. Partai Islam, Partai Islam di Pentas Nasional: Kisah dan Analisis Perkembangan Politik Indonesia 1945-1965. Bandung: Mizan, 2000. 
Rahman, Budhy Munawar. Doktrin Islam Dalam Sejarah. Jakarta: Paramadina, 1995.

Ramage, Douglas E. Percaturan Politik di Indonesia: Demokrasi, Islam, dan Ideologi Toleransi, alih bahasa Hartono Hadikusumo. Jogjakarta: Mata Bangsa, 2002.

Rosidi, Ajib dan M. Natsir. Sebuah Biografi. Jakarta: Girimurti Pustaka, 1990.

Suhelmi, Ahmad. Polemik Negara Islam: Soekarno Versus Natsir. Bandung: Teraju, 2002.

Ulum, Bahrul. Bodohnya NU Apa NU Dibodohi?, Jejak Langkah NU Era Reformasi: Menguji Khittah Meneropong Paradigma Politik. Yogyakarta: Ar-Ruzz, 2002.

Wahid, Abdurrahman. Mengurai Hubungan Agama dan Negara. Jakarta, Grasindo, 1999.

Zada, Khamami. Neraca Gus Dur di Panggung Kekuasaan. Jakarta: Lakpesdam, 2002. 